\title{
Literature Review of the Potential Energy Savings and Retention Water from Green Roofs in Comparison with Conventional Ones
}

\author{
Kyriakoulis Tselekis, Utrecht University
}

\begin{abstract}
The objective of this study is the comparison of green roof systems with conventional isolated and non-isolated ones in order to identify the potential energy savings of green roofs and the benefits provided in comparison with the cost of construction to the buildings. The region of interest is the Watergraafsmeer area in the city of Amsterdam. The method evaluates literature reports - mostly from 2003 to 2010 - that present the advantages of green roofs. Examples in real implementation of green roofs in USA, UK and Germany, retention of rainfall and a Life Cycle Assessment from a residential construction in Madrid will be introduced, showing the energy savings from insulation and heating/cooling that can be gained. All the reports have shown a reduction in energy costs and in runoff of water. Hence, costs and retrofitting potential completes the research. The age of buildings and the absence of insulation make green roofs an ideal alternative project for the retrofit of Watergraafsmeer.
\end{abstract}

Keywords - energy savings, retention, insulation, retrofit

\section{INTRODUCTION}

Buildings account for almost half of primary energy consumption, consumption that results in $\mathrm{CO}_{2}$ emissions in developed cities (including Amsterdam). A large amount of this energy is used to maintain the internal building temperatures through heating and cooling systems. Impervious surfaces absorb and reradiate solar radiation creating what is known as the "urban heat island" effect, where average air temperatures in highly developed areas are much higher than in the surrounding landscapes [15]. This high temperature leads to an increase in a building's cooling costs, particularly during the summer.

A very promising solution for the reduction of emissions and the consumption of energy is the green roofs project. The distinguishing feature of green roofs is their low solar absorbance and reflectivity of solar radiation, which leads to lower surface temperatures. In addition, the heat flux through the roof is also reduced. Direct shading, evaporative cooling and photosynthesis permit plants to control surface temperatures and the microclimate around the area. Moreover, the decline in roof temperature may decrease long wave radiation emitted by the building surface, thus contributing to the reduction of the urban "heat island effect" in the city [16].

The purpose of this research is to evaluate the possible solutions provided by recent studies for the reduction of energy costs with the use of green roofs and how these projects can be used in the Watergrafmeer area in Amsterdam. A green roof contributes to storm water treatment. The reduced amount of runoff handled by the city's sewage decreases the chance/risk of flooding but also results in lower treatment costs owing to there being less water to process. The retrofitting of old buildings is more beneficial in comparison with the advantages given by insulation with the conventional methods already exist in the market. Furthermore, changing to a more environmentally friendly building design can lead to improvements in the quality of citizens' lives as well as in the appearance of the area.

Current Netherlands building regulations require the roof Ufactor $^{1}$ to be $0.20-0.25 \mathrm{~W} / \mathrm{m} 2 \mathrm{~K}$. The new buildings have higher standards of insulation than buildings built before the adoption of the current regulations, meaning that existing buildings have to comply with the new regulation. Life cycle assessment $(\mathrm{LCA})^{2}$ is a well-known method for evaluating environmental impacts in the building sector [16]. LCA is used to evaluate the benefits from reduced energy consumption resulting from the addition of a green roof residential building.

Green roofs are typically divided into two main categories: extensive and intensive. Extensive green roofs have thin substrates $(5-15 \mathrm{~cm})$, limited plant palates, lower costs and nominal weight requirements. On the other hand, intensive green roofs, also named as "rooftop gardens", have deeper substrates $(>15 \mathrm{~cm})$ which let for higher potential for increased plant diversity but also come with increased weight, higher costs and maintenance requirements in comparison with extensive ones [3].

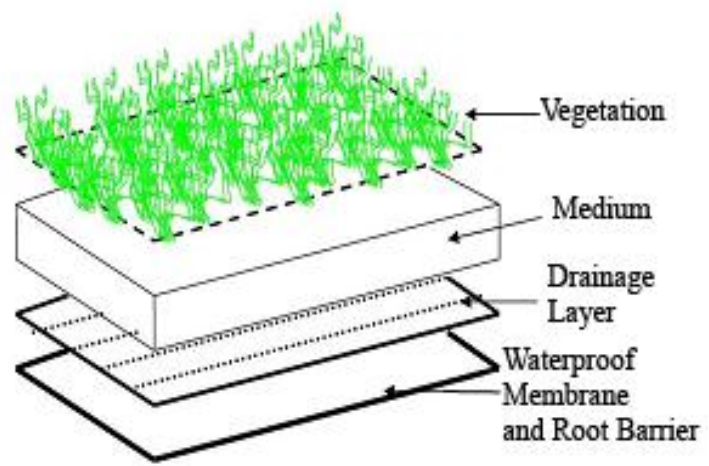

Fig. 1. Typical cross-section of a green roof system [24]

${ }^{1}$ U-factor: Also known as the $U$-value or coefficient of heat transmission, which is a measure of the rate of non-solar heat loss or gain through a material.

${ }^{2}$ Life cycle assessment: A 'Life Cycle Assessment'('LCA', also known as 'life cycle analysis') is the investigation and evaluation of the environmental impacts of a given product or service caused or necessitated by its existence. 


\section{METHODS}

A literature review of green roof projects was undertaken to collect data published mainly during the period 2003-2010. Field measurements were introduced by the Universities in Georgia, Tufts in USA, in comparison with several studies conducted mainly in Germany, in order to measure the evaporative cooling effect $^{3}$ of a green roof, which is considered to play an important role in the reduction of heat flux and the retention of water. All other weather conditions, like humidity, remained the same for all cases. Germany was chosen due to comparable climatic conditions with the Netherlands [26]. The results of these measurements are presented in table I.

A life cycle assessment (LCA) was chosen as the appropriate method for evaluation of the long-term environmental impacts of a project, such as a green roof by Sainz et al. in 2006 [16]. In the beginning, a bottom-up LCA was conducted assuming a 50 year building life. The reference case is an eight story residential building in Madrid. The first step is LCA with a conversional flat roof, in order to set up indicators. The life cycle impacts are quantified for the addition of a green roof [16]. The annual precipitation of the area is $436 \mathrm{~mm}$ with the percentage of humidity to be $57 \%$. Alternatives were selected. We selected a Madrid standard gray gravel flat roof (BFR), a green roof (BGR), and a white roof with a reflective layer (BWR). They have different characteristics, as shown in Figure IV the solar absorbance is an important characteristic of the roof. Details of the structure of each of the roofs were excluded and the focus will be on the results. LCA showed that there are differences in solar absorbance between the different materials. The area of Watergraafsmeer was chosen due to characteristics of the area. Watergraafsmeer mainly comprises a polder. It is located 5.5 $\mathrm{m}$ below sea level (the lowest part of Amsterdam), which makes it a residential area vulnerable to water-related problems such as flooding. Moreover, the age of buildings starts from the beginning of the $20^{\text {th }}$ century that makes the area ideal for retrofit [21]. A typical green room system is presented in Figure I. [24]. For the energy savings from the implementation of a green roof a case study of a Dutch household will be presented. All the equations and values provided in the tables of the case study are coming from the book: Kornelis Blok, Introduction to Energy Analysis, 2007. In this case study an investigation of the energy balance of a Dutch house will be introduced.

\section{Case study: Energy balance in a Dutch house.}

We will investigate the energy balance of a house. The average energy consumption of a Dutch household is given in table I. The following HHV value for natural gas: $35.1 \mathrm{MJ} / \mathrm{m}^{3}$.
TABLE I

ENERGY CONSUMPTION OF A DUTCH HOUSEHOLD PER YEAR

\begin{tabular}{|cl|l|}
\hline \multicolumn{2}{|c|}{ Application } & Consumption \\
\hline 1. & Heating & $1575 \mathrm{~m}^{3}$ natural gas \\
\hline 2. & Cooking & $65 \mathrm{~m}^{3} \quad$ natural gas \\
\hline 3. & Warm water & $380 \mathrm{~m}^{3} \quad$ natural gas \\
\hline 4. & Electricity & $3255 \mathrm{~m}^{3} \mathrm{kWh}$ \\
\hline
\end{tabular}

In the model below we make the following assumptions. The house has two rectangular floors $(6 \mathrm{~m}$ width* $12 \mathrm{~m}$ long* $3 \mathrm{~m}$ high) and a ceiling with a saddle (peaked) roof. The roof has an angle of $45^{\circ}$ and is insulated with mineral wool of $30 \mathrm{~mm}$ thick. The ridge of the roof is parallel to the short side of the house and is thus 6 meters long. $15 \%$ if the vertical surface of the first two floors consists of double glass. The walls are insulated cavity walls, the floor is medium insulated. The house has a boiler with an efficiency of $90 \%$ (HHV).

TABLE II

GENERAL INFORMATION

\begin{tabular}{|l|l|}
\hline \multicolumn{2}{|c|}{ General information - Calculations } \\
\hline Efficiency boiler 90\% HHV & \\
\hline Lower Heating Value (LHV) & $31.65 \mathrm{MJ} / \mathrm{m} 3$ \\
\hline Higher Heating Value (HHV) & $34.815 \mathrm{MJ} / \mathrm{m} 3(=1.1 * \mathrm{LHV})$ \\
\hline Electricity & $3.6 \mathrm{MJ} / \mathrm{kWh}$ \\
\hline Heating & $1575 \mathrm{~m} 3 / \mathrm{yr} 54834 \mathrm{MJ} / \mathrm{yr} 1738.8 \mathrm{~W}$ \\
\hline Cooking & $65 \mathrm{~m} 3 / \mathrm{yr} 2263 \mathrm{MJ} / \mathrm{yr} 71.8 \mathrm{~W}$ \\
\hline Warm water & $380 \mathrm{~m} 3 / \mathrm{yr} 13230 \mathrm{MJ} / \mathrm{yr} 419.5 \mathrm{~W}$ \\
\hline Electricity & $3255 \mathrm{kWh} / \mathrm{yr} 11718 \mathrm{MJe} / \mathrm{yr} 371.6 \mathrm{~W}$ \\
\hline TOTAL & $2601.6 \mathrm{~W}$ \\
\hline
\end{tabular}

In order to determine the total heat transmission coefficient of the walls, the floor, the roof and the glass, the data provided by using the tables below will be used. Thermal resistance at the outside of the wall is $0.04 \mathrm{~m}^{2} \mathrm{~K} / \mathrm{W}$ and at the inside 0.13 $\mathrm{m}^{2} \mathrm{~K} / \mathrm{W}$. The outside resistance is only applicable for vertical and tilted surfaces.

TABLE III

HEAT TRANSMISSION COEFFICIENT OF SEVERAL BUILDING STRUCTURES

\begin{tabular}{|l|c|c|c|c|}
\hline & $\begin{array}{c}\text { Temp } \\
{[\mathbf{K}]}\end{array}$ & $\begin{array}{c}\text { Total heat trans } \\
\text { Coefficient, } \\
{\left[\mathbf{W} /\left(\mathbf{m}^{\mathbf{2}} \cdot \mathbf{K}\right)\right]}\end{array}$ & $\begin{array}{c}\text { Surface } \\
{\left[\mathbf{m}^{\mathbf{2}}\right]}\end{array}$ & $\begin{array}{c}\text { Heat } \\
\text { Flux } \\
{[\mathbf{W}]}\end{array}$ \\
\hline Floor & 0.5 & 0.56 & 72.0 & 20.04 \\
\hline Wall & 1 & 0.63 & 255.6 & 159.89 \\
\hline Glass & 1 & 1.99 & 32.4 & 64.37 \\
\hline Roof & 1 & 0.54 & 101.8 & 55.44 \\
\hline \multicolumn{5}{|l}{ Total difference in temperature: } \\
\hline
\end{tabular}

\footnotetext{
${ }^{3}$ Evapotranspiration (ET) is a term used to describe the sum of evaporation and plant transpiration from the Earth's land surface to the atmosphere. Evaporation accounts for the movement of water to the air from sources such as the soil, canopy interception, and water bodies. Transpiration accounts for the movement of water within a plant and the subsequent loss of water as vapor through stomata in its leaves. (The definition retrieved from Wikipedia)
} 
TABLE IV

HEAT TRANSMISSION COEFFICIENT OF BUILDING STRUCTURES

\begin{tabular}{|l|c|}
\hline Building structure & $\begin{array}{l}\text { Heat transmission } \\
\text { Coefficient } \mathbf{~} / \mathbf{m}^{\mathbf{2}} / \mathbf{K}\end{array}$ \\
\hline Glass single & 6 \\
\hline Glass double & 3 \\
\hline Glass triple & 2 \\
\hline Cavity wall & 1.8 \\
\hline Floor & 0.6 \\
\hline Insulated $(50 \mathrm{~mm})$ cavity wall & 0.7 \\
\hline Tilted roof & 3 \\
\hline Insulated $(30 \mathrm{~mm})$ tilted roof & 0.6 \\
\hline
\end{tabular}

TABLE V

HEAT TRANSMISSION OF ROOF

\begin{tabular}{|c|c|c|c|}
\hline \multirow{4}{*}{ Roof } & $\begin{array}{c}\text { Heat } \\
\text { transmission } \\
\text { coefficient }(\mathrm{K}) \\
{\left[\mathrm{W} /\left(\mathrm{m}^{2} \cdot \mathrm{K}\right)\right]}\end{array}$ & $\begin{array}{c}\mathrm{R}(=1 / \mathrm{k}) \\
{\left[\left(\mathrm{m}^{2} \cdot \mathrm{K}\right) / \mathrm{W}\right]}\end{array}$ & $\begin{array}{c}\text { Rinside } \\
{\left[\left(\mathrm{m}^{2} \cdot \mathrm{K}\right) / \mathrm{W}\right]}\end{array}$ \\
\hline & 0.6 & 1.67 & 0.13 \\
\hline & $\begin{array}{c}\mathrm{R}_{\text {outside }} \\
{\left[\left(\mathrm{m}^{2} \cdot \mathrm{K}\right) / \mathrm{W}\right]}\end{array}$ & $\begin{array}{c}\mathrm{R}_{\text {total }} \\
{\left[\left(\mathrm{m}^{2} \cdot \mathrm{K}\right) / \mathrm{W}\right]}\end{array}$ & $\begin{array}{l}\text { Total heat transmission } \\
\text { coefficient }\left[\mathrm{W} /\left(\mathrm{m}^{2} \cdot \mathrm{K}\right)\right]\end{array}$ \\
\hline & 0.04 & 1.84 & 0.54 \\
\hline
\end{tabular}

In order to calculate the energy flux out of the house there is an assumption of $\Delta \mathrm{T}$ of 1 degree.

\section{RESULTS}

The results will be divided into three categories: Retention of water, energy savings and retrofit potential

\section{Retention of water}

Studies conducted in the universities in USA (Tufts, Georgia) showed a high retention of water. Figure 1 measures the retention rate of Georgia and Tufts at $67 \%$ and $78 \%$ respectively. The above figures are useful in so far as proving the water retention effectiveness of green roofs, however in terms of climate and building type; Berlin is a much better indicator of potential water retention rates. A comparison between Berlin, Brussels and Amsterdam was conducted. The similarities between Brussels, Berlin and Amsterdam can be found in the annual precipitation rates which are $600-650 \mathrm{~mm}$ [24], 550-650mm and 600-780mm respectively. In Berlin achieved a $75 \%$ retention rate with $550-650 \mathrm{~mm}$ of precipitation/year [9]. These findings do not differ from the results presented by Jeroen Mentens in 2005, for Brussels. Retention may range from $75 \%$ for intensive green roofs (median substrate depth: $150 \mathrm{~mm}$ ) to $45 \%$ for extensive green roofs (median substrate depth: $100 \mathrm{~mm}$ ). The average annual precipitation in Amsterdam is $600-780 \mathrm{~mm}$ as shown in Figure III, which means that retention of water from green roofs can be expected to be similar. Another important factor in addition to the precipitation of the area is the materials used for the construction of a green roof and the depth of the substrate. A media depth of $2.5 \mathrm{in}$. $(6.5 \mathrm{~cm})$ can retain $40 \%$ of the rain as reported by Scholz-Barth, in 2001. Furthermore, several studies conducted in Germany have shown that a green roof with a substrate depth of 2 to $4 \mathrm{~cm}$ with a vegetation mix of mosses and sedum can retain 40 to $45 \%$ of the annual rainfall that falls on it [25]. By increasing the depth of the substrate from 10 to $15 \mathrm{~cm}$ and changing the vegetation to a mixture of sedum, grasses, and herbs, green roofs can retain up to $60 \%$ of storm water on an annual basis [25].

The effectiveness of a green roof is also affected by the season. During summer the roofs reach their highest retention rates that reduced scientifically during winter periods. According to the ZinCo planning guide (1998), living roofs are normally able to retain 70 to $90 \%$ of the stormwater that falls on them during the summer months, depending on the frequency of rain and drying rates. In winter months, green roofs are predicted to retain $40-50 \%$ of the stormwater [28]. These values are similar with the findings of the Environmental Protection Agency (EPA) in the United States. EPA reported that during the summer months, nearly $95 \%$ of the precipitation was retained. During winter, retention was smaller (20\%) [27]. A summary of the results from all the previous studies are presented in table VI.

\section{TABLE VI}

SUMMARY OF THE MAIN PRECIPITATION RATES, RAINFALL RETENTION AND LOCATION OF THE RESEARCH

\begin{tabular}{|c|c|c|c|c|c|c|}
\hline Age & $\begin{array}{l}\text { Refe- } \\
\text { rence }\end{array}$ & $\begin{array}{c}\text { Substrate } \\
(\mathbf{m m})\end{array}$ & Location & $\begin{array}{c}\text { Yearly } \\
\text { precipitat } \\
\text { ion }(\mathbf{m m})\end{array}$ & $\begin{array}{c}\text { Rainfall } \\
\text { retained } \\
\text { green } \\
\text { roofs } \\
(\%)\end{array}$ & Season \\
\hline 1998 & $\begin{array}{l}\text { ZinCo } \\
\text { guide }\end{array}$ & --- & Germany & 600 & $70-90$ & Summer \\
\hline 1998 & $\begin{array}{l}\text { ZinCo } \\
\text { guide }\end{array}$ & --- & Germany & 600 & $40-50$ & Winter \\
\hline 2009 & EPA & --- & USA & --- & 95 & Summer \\
\hline 2009 & EPA & --- & USA & --- & 20 & Winter \\
\hline 2001 & $\begin{array}{l}\text { Scholz- } \\
\text { Barth }\end{array}$ & $65 \mathrm{~mm}$ & & & 40 & \\
\hline 2005 & $\begin{array}{c}\text { Jeroen } \\
\text { Mentens }\end{array}$ & $\begin{array}{l}150 \\
\mathrm{~mm}\end{array}$ & Belgium & $600-650$ & 75 & --- \\
\hline 2005 & $\begin{array}{c}\text { Jeroen } \\
\text { Mentens }\end{array}$ & $100 \mathrm{~mm}$ & Belgium & $600-650$ & 45 & --- \\
\hline 2001 & $\begin{array}{c}\text { Kohler, } \\
\text { M., }\end{array}$ & & Germany & $550-650$ & 75 & --- \\
\hline & [25] & $40 \mathrm{~mm}$ & Germany & --- & $40-45$ & \\
\hline & [25] & $150 \mathrm{~mm}$ & Germany & --- & 60 & Summer \\
\hline 2008 & Hilten, R & & USA & & $67-78$ & Summer \\
\hline
\end{tabular}

A media depth of 2.5 in. $(6.5 \mathrm{~cm})$ can retain $40 \%$ of the rain as reported by Scholz-Barth, in 2001. Furthermore, several studies conducted in Germany have shown that a green roof with a substrate depth of 2 to $4 \mathrm{~cm}$ with a vegetation mix of 
mosses and sedum can retain 40 to $45 \%$ of the annual rainfall that falls on it [25]. By increasing the depth of the substrate of 10 to $15 \mathrm{~cm}$ and changing the vegetation to a mixture of sedum, grasses, and herbs, green roofs can retain up to $60 \%$ of storm water on an annual basis [25].

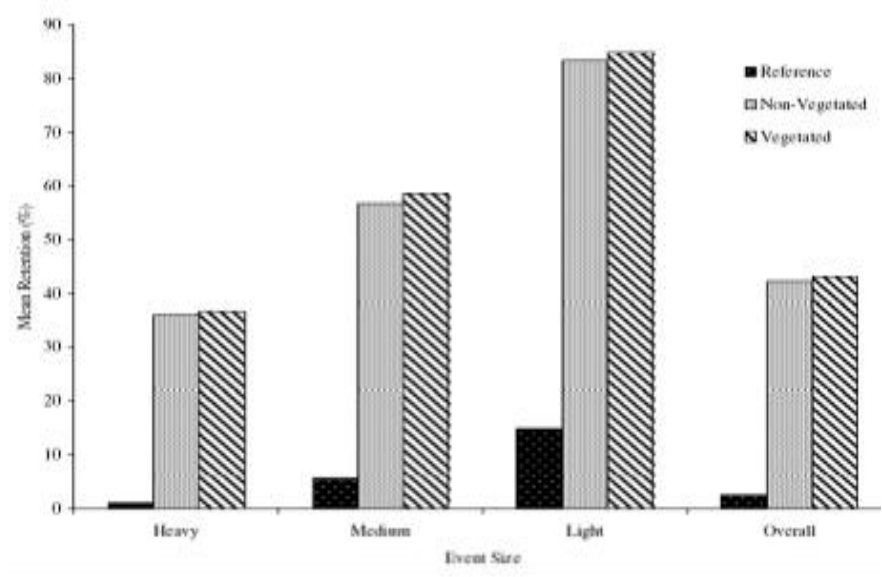

Fig. 2. Percent retention for different sized storms and treatments of UGA system Light storms $<6 \mathrm{~mm}$, Medium $6-25 \mathrm{~mm}$ and Heavy storms were $>25 \mathrm{~mm}$. The image retrieved from [2].

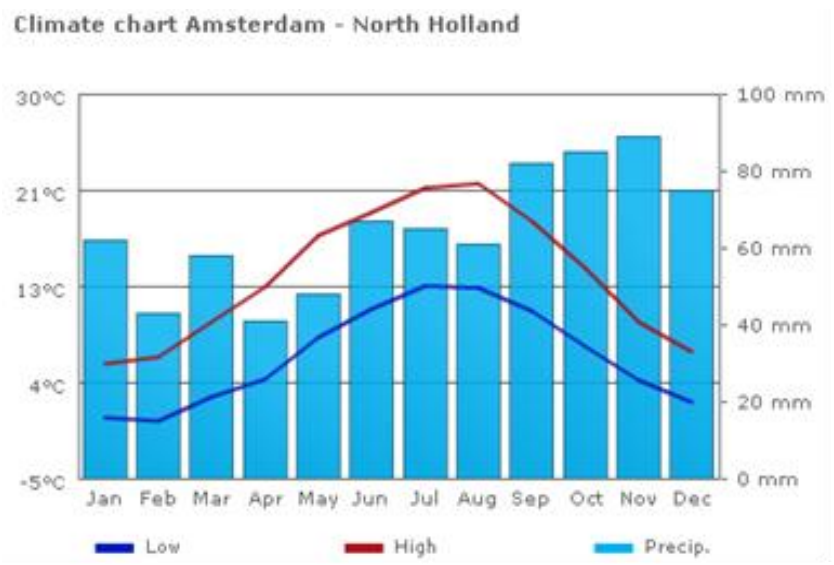

Fig. 3. Yearly weather conditions in Amsterdam, the Netherlands, 2009. The image retrieved from [20]

\section{Energy savings \& Retrofit potential}

In table VII, the results from the LCA in Madrid are presented. From the comparison between a standard gray gravel flat roof (BFR), a green roof (BGR), and a white roof with a reflective layer (BWR) it can be noticed that green roof has the lower solar absorbance - higher solar reflectivity-. This factor is significant for the energy savings. In addition, the larger the covered area the higher the energy savings that come from green roofs [10]. The energy efficiency is reduced per floor and after the first three floors from the top these savings are negligible, as shown in figure IV.

A UK study showed high energy saving for green roofs, resulting in a $44 \%$ annual energy savings for non-insulated roofs in comparison to $7 \%$ for moderately insulated roofs, as shown in table VIII. Given the corresponding building types present in the UK and Netherlands, similar results can be expected pertaining to the energy saving potential of green roofs in the Netherlands. Energy savings for heating can be as high as $45 \%$ of non-insulated buildings and $13 \%$ in insulated ones.

The Green Roof Centre in UK, make estimations about the cost of extensive green roof system. The cost is between 65 to 115 euro/m2. The price depends from variables such as the age of the building or the need for additional constructions in the roof (Castleton et al., 2010). Other parties give different prizes. The Lambeth Council which specialized in real green roof retrofit gives an average between 140 to 200 euro/m2. Carter and Keeler (2008), made a life cost analysis and they estimated the Net Present Value ${ }^{4}$ of a green roof to be $10-14 \%$ more expensive than a conventional roof.

Nevertheless one needs to take into account that the higher energy costs and the future cost reduction for green roofs in comparison with the cost of flooding or prevention measures for storm water will make green roof a more economically attractive proposal. If we combine these assumptions we come to the conclusion that the green roof project has benefits for the area. Most of the buildings in the area were constructed during the 1900s. This means firstly that they do not have proper insulation. The level of insulation is an important factor for the energy saving of green roofs. Niarchou et al. (2001) have reported that energy consumption in a range from $40 \%$ to $2 \%$ for non- insulated to well insulated, respectively.

Hence the energy consumption of these buildings is high. In addition no more additional structure needed in order to put green roofs. The conclusion is that the cost is higher instead of a conventional roof but for this specific area the benefits are higher.

TABLE VII

THERMAL AND OPTICAL PROPERTIES OF DIFFERENT ROOF MATERIALS UNDER DRY CONDITIONS. THE TABLE RETRIEVED FROM [16].

\begin{tabular}{|l|c|c|c|}
\hline Roof type & $\begin{array}{c}\text { Conductance } \\
\text { (W/m2 C) }\end{array}$ & $\begin{array}{c}\text { Thermal } \\
\text { Capacity (kJ/ C) }\end{array}$ & $\begin{array}{c}\text { Solar } \\
\text { Absorbance }\end{array}$ \\
\hline $\begin{array}{l}\text { Common flat roof } \\
\text { (BFR) }\end{array}$ & 0.59 & 479 & 0.8 \\
\hline $\begin{array}{l}\text { White roof } \\
\text { (BWR) }\end{array}$ & 0.59 & 479 & 0.4 \\
\hline $\begin{array}{l}\text { Green roof } \\
\text { (BGR) }\end{array}$ & 0.59 & 519 & 0.37 \\
\hline
\end{tabular}

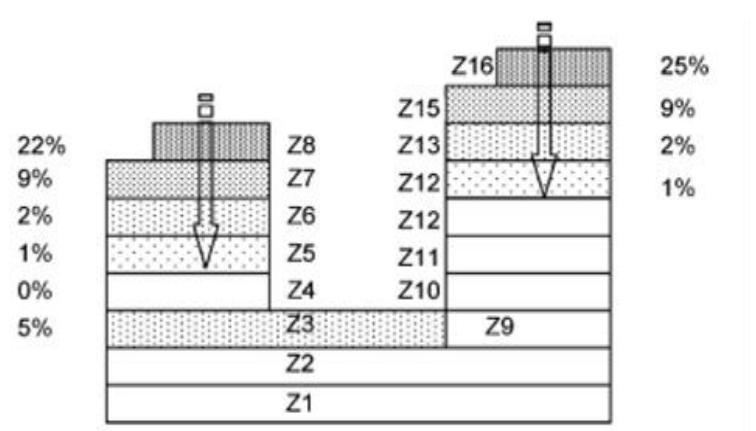

Fig. 4. Peak cooling energy reductions reached in the first four floors of the building with the addition of green roof. The figure retrieved from [16].

\footnotetext{
${ }^{4}$ Net present value: In finance, the net present value (NPV) or net present worth (NPW) of a time series of cash flows, both incoming and outgoing, is defined as the sum of the present values (PVs) of the individual cash flows
} 
TABLE VIII

ENERGY SAVING POTENTIAL OF GREEN ROOF ON LOW, MODERATELY \& HEAVY INSULATED BUILDINGS IN UK. TABLE RETRIEVED FROM [4].

\begin{tabular}{|l|c|c|c|c|c|}
\hline Roof & $\begin{array}{c}\text { U-value } \\
\text { Without } \\
\text { green roof } \\
\text { (W/m2 K) }\end{array}$ & $\begin{array}{c}\text { U-value } \\
\text { with } \\
\text { green roof } \\
\text { (W/m2 K) }\end{array}$ & $\begin{array}{c}\text { Annual } \\
\text { energy } \\
\text { savings } \\
\text { \% for } \\
\text { heating }\end{array}$ & $\begin{array}{c}\text { Annual } \\
\text { energy } \\
\text { savings } \\
\text { \% for } \\
\text { cooling }\end{array}$ & $\begin{array}{c}\text { Total } \\
\text { annual } \\
\text { energy } \\
\text { saving }\end{array}$ \\
\hline $\begin{array}{l}\text { Well } \\
\text { insulated }\end{array}$ & $0.26-0.4$ & $0.24-0.34$ & $8-9 \%$ & 0 & $2 \%$ \\
\hline $\begin{array}{l}\text { Moderately } \\
\text { insulated }\end{array}$ & $0.74-0.80$ & $0.55-0.59$ & $13 \%$ & $0.4 \%$ & $3-7 \%$ \\
\hline $\begin{array}{l}\text { Non } \\
\text { insulated }\end{array}$ & $7.76-18.18$ & $1.73-1.99$ & $45-46 \%$ & $22-45 \%$ & $31-$ \\
\hline
\end{tabular}

\section{DISCUSSION}

This research was conducted in June 2010 in order to investigate the benefits that can be provided by green roofs to the citizens in the Watergraafsmeer area in Amsterdam. The literature being used in this study is from the period of

2003-2010, with an exception of five papers that were older $[6,9,12,13,14])$. The results of the studies were in agreement, showing the energy savings and the storing potential of water from the projects. In most of the cases the data provided does not give the same values, but this was expected due to projects being in different seasons and areas. This was the main drawback with the literature in order to make comparable results. Regarding energy savings, green roofs can reduce energy use for heating in winter and cooling in the summer. The energy benefits are much higher for non insulated houses and less for well insulated (only 2-3\%). But even then, the importance of green roofs in the retention of the water and the design of the building cannot be neglected. After the first three floors below the roof the benefits of a green roof are negligible. A dry substrate (soil) with less density and higher porosity is a better insulator. In the area of Watergraafsmeer the heating losses may be higher (more rainfalls $\rightarrow$ wet substrate) and the costs higher to construct a heavier substrate, but it also depends on the plantation, which enhances retention. The bigger the area covered by green roofs the better the results but also higher the costs. As mentioned in a previous section of this study, the average cost is $150 \mathrm{euro} / \mathrm{m}^{2}$, depending on whether it is for a new building or for retrofitting.

Another important aspect in a green roof project is the retention of water. Retention between 33\% - 50\% (it depends from the area and the system) is important for reduction of the storm water problems. Water is stored by the substrate and then taken up by the plants, from where it is returned to the atmosphere through transpiration and evaporation. Retention depends on the area and the system. During the summer, depending on the plantation and the depth of growing medium, green roofs have higher rates of retention of water. Green roofs can retain $70-90 \%$ of the precipitation. In winter they retain between $25-40 \%$. For example, a grass roof with a 4-20 $\mathrm{cm}$ (1.6 - 7.9 inches) layer of growing medium can hold 10-15 $\mathrm{cm}$ (3.9 - 5.9 inches) of water.
In winter green roofs are less efficient. As for the hurdles that need to be overcome, the lack of regulatory incentives, design guidelines and building standards are the most important. Moreover, the public needs to be informed about the advantages of green roofs because they are still not familiar with this technology. A further reduction of costs will reduce the gap between conventional insulation and the use of green roofs for this role. There are also deficiencies regarding the long term performance of the project. In general there is no evidence that it will not perform well, but on the other hand difficulties in repairing parts of green roofs (such as the substrate) and the uncertainties for lifetime of materials, like the membranes, are not to be neglected and need further investigation.

\section{CONCLUSIONS}

The energy benefits from the construction of a green roof project in the buildings of Watergraafsmeer area are very high because these projects can reduce the energy use for heating in the winter and cooling in the summer. There are non insulated and insulated buildings and these represent $50 \%$ and $5 \%$ percent respectively. With assumptions that $15 \%$ of these buildings can be retrofitted an annual energy saving with a value of 5.4 PJ could be achieved (Castleton, 2010).

The age of the building is an important factor. As mentioned above a large number of old and non-insulated buildings exist, so the combination of insulation and energy savings can make the green roof an attractive option for retrofitting. The construction cost for a green roof is similar to the cost of a conventional insulation system. A green roof can be $10-14 \%$ more expensive than a conventional roof.

The problem of flooding and storm water treatment is important for Watergraafsmeer citizens due to the direct costs such as repairing of the buildings and indirect such as the drawback in the growth of the area. Green roofs can be an attractive project with lower costs in comparison with the costs for maintenance of the sewage system or costs of flooding or other massive end of pipe treatment installations that need to be applied in the Watergraafsmeer area. It is also a project that can be easily combined with other prevention measures such as central underground water reservoir.

Environmentally friendly design may give a higher value to the area and the life expectancy of the roof. The main limitations surrounding green roofs are the lack of knowledge of the public and incentives from the government. It is not only important that actions that lead to informing citizens through campaigns and advertisements as to the benefits of the project be taken up, but also that there are incentives to make them economically feasible.

\section{REFERENCES}

1. Berndtsson, J., C. Green roof performance towards management of runoff water quantity \& quality: a review. Sweden: Lund University. Department of water Resources Engineering, 2010

2. Butler, C., Carter, T. Ecological impacts of replacing traditional roofs with green roofs in two urban areas. Boston College: Urban Ecology Institute, 2008. vol. 1, article 9

3. Carter, T., Keeler, A. Life cycle cost benefit analysis of extensive vegetated roof systems, 2008. Journal of Environmental Management 87 
4. Castleton, H. F., Stovin, V., Beck, S. B. M., et al. Green roofs; Building energy savings and the potential for retrofit. Sheffield: Department of civil and structural engineering. Energy and buildings, 2010. vol.42, p. 1582-1591.

5. Compton, J. Rethinking the green roof. 2006.

6. Eumorfopoulou, E., Aravantinos, D. The contribution of a planted roof the thermal protection of buildings in Greece. Energy and buildings, 1998. vol.27, p. 29-36.

7. FiBRE. Findings in Built and Rural Environments, Can Greenery Make Commercial Buildings More Green? Cambridge University, 2007.

8. Hilten, R., Lawrence, T., M., Tollner, E., W. Modeling storm water runoff from green roofs with HYDRUS-1D. United States: University of Georgia: Department of biological and Agricultural Engineering, 2008

9. Kohler, M., Schmidt, M., Grimme, W., et al. Urban water retention by greened roofs in temperate and tropical climate. Technical University of Berlin, 2001

10. Martens, R., Bass, B., Alcazar, S. Roof-envelope ratio impact on green roof energy performance. Toronto: Adaption and impacts Research Division, 2008. vol. 11, p. 399-408.

11. Miller, V., Fuchs, A., Rossi, G., et al. Green roofs: Alleviating urban stress. University of Pittsburgh: Department of Mechanical Engineering, 2007.

12. Niachou, A., Papakonstantinou, K., Santamouris, M., et al. Analysis of the green roof thermal properties and investigation of its energy performance. Energy and buildings, 2001. vol.33, p. 719-729.

13. Onmura, S., Matsumoto, M., Hokoi, S. Study on evaporative cooling effect of roof lawn gardens. Osaka: Technical Research Institute. Energy and buildings, 2000. vol.33, p. 653-666.

14. Palomo Del Barrio,. E. Analysis of the green roofs cooling potential in buildings. Energy and buildings, 1998. vol.27, p. 179-193.

15. Rizwan, A., Dennis, Y., Liu, C. A review on the generation, determination, mitigation of Urban Heat Island. Journal of Environmental Science and Technology, 2008. vol.20, p. 120-128.

16. Sainz, S., Kennedy, C., Bass, B., et al. Comparative Life Assessment of Standard and Green Roofs. University of Toronto: Department of civil engineering. Environmental science and technology, 2006. vol.40, p 4312-4316.

17. Scholz-Barth, K. Green roofs: Storm water management from the top down. Environmental Design and Construction Magazine, 2003

18. Spala, A., Bagiorgas, H., S., Assimakopoulos, M., et al. On the green roof system selection, state of the art and energy potential investigation of a system installed in an office building in Athens, Greece. Athens: University of Ioannina: Department of environmental and natural resources management, 2007
19. Stovin, V. The potential of green roof to manage urban storm water. UK: University of Sheffield. Department of civil and structural Engineering, 2010

20. www.Climatedata.Eu

21. http://www.jlgrealestate.com

22. http://livingroofs.org/

23. Mentens, J. et al., Green roofs as a tool for solving the rainwater runoff problem in the urbanized 21th century. Department of Land Management, Laboratory for Forest, Nature \& Landscape Research, KULeuven, Belgium

24. Survey of research related to green roofs: Report on the Environmental Benefits and costs of green roof technology for the city of Toronto

25. Beckman, B., Buishand, T. Statistical downscaling relationships for precipitation in the Netherlands and North Germany. Royal Meteorological Institute, the Netherlands. 2001

26. United States Environmental Protection Agency: Green Roofs for stormwater runoff control. 2009

27. Zingo: Engineered Green Roof systems: Planning Guide

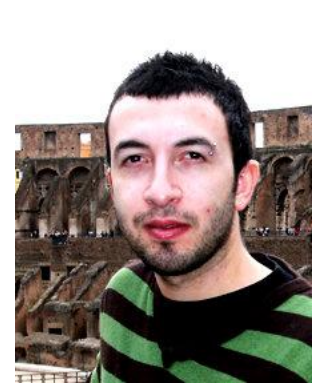

Kyriakoulis Tselekis was born in 1982, in Sparta, Greece. He received both his Bsc and Msc in Environmental Management and Natural Resources from the University of Ioannina, Greece. He took his degree in 2006. In 2009 he began a Msc in Sustainable Development, Energy and Resources at Utrecht University, from which he expects to graduate by December 2012.

Kyriakoulis Tselekis currently is a Msc STUDENT at the University of Utrecht. Previous working experiences include working for Microsoft Greece as a SALES MANAGER, for Liberis Publications as a MARKETING ANALYSER. He has worked as an ENVIRONMENTAL CONSULTANT at Machairas Consultancy.

In June 2011 he was finalist at the International Energy Battle in the Netherlands with the project "Sustainable cargo transportation through space". He won a Bakalas scholarship for excellence in performance $(2009-2011)$ He received an honorary qualification from the University of Ioannina for graduating $3^{\text {rd }}$ in his class. His main research interest concerns energy saving in households

Address: Javastraat 17bis, 3531PL

Phone: +31(0)644048 996

E-mail: ktselekis@gmail.com 